\title{
In Memoriam a José Jara
}

Una frase de Nietzsche me persigue al enterarme de la muerte anunciada de mi amigo Pepe Jara: "Hay que abandonar la vida como Ulises se separó de Nausicaa: bendiciéndola más bien que enamorado de ella". Volví a ver a Pepe el mes recién pasado en Santiago, enflaquecido, apoyándose en un bastón, hermoso y más elegante y dandi que nunca, con sus ojos risueños revelando una sonrisa eterna disimulada tras un bigote digno de un bailarín de tango y de un violinista (que también lo era), en obstinada negación de toda complacencia consigo y la confesión de la gravedad de su enfermedad. Los retornos a Chile del profesor José Jara, que conocía mejor que nadie la obra de Nietzsche, son, por demás, como la imagen de Ulises en Grecia. Habiendo partido voluntariamente de su país para hacer un máster en la Universidad de Texas, llega a ser, a su vuelta, profesor de Filosofía en la Universidad de Valparaíso, combinando indistintamente un curso de filosofía celebrado ya en esa época como ningún otro en el paisaje universitario chileno, y una atención dirigida a la reforma universitaria, es decir, a la universidad por-venir. Expulsado de su cátedra por el golpe militar, parte nuevamente de Chile, apremiado y forzado, por segunda vez, y va a obtener un doctorado de filosofía en la Universidad de Münich en 1975; luego enseña en la Universidad Central de Caracas, para finalmente dirigir el prestigioso Departamento de Filosofía de la Universidad Simón Bolívar de Caracas, fundado por Ernesto Mayz Vallenilla. De vuelta de su segundo exilio, nuevamente es la Universidad de Valparaíso la que le acoge, permitiéndole cumplir su destino: el de un gran profesor de Filosofía que habrá marcado duraderamente el fin de siglo formando con su enseñanza, la nueva generación filosófica chilena y participando activamente en la defensa de la universidad pública y en la reflexión sobre el lugar de la enseñanza filosófica en el cursus studiorum. Su obra publicada también es considerable, desde su traducción del Gay saber de Nietzsche hasta la publicación de Nietzsche, pensador póstumo: el cuerpo como centro de gravedad, que es un gran libro de filosofía.

José Jara: un gran profesor, pero para quien la Universidad no es ella misma sino yendo más allá de sí misma; y un filósofo auténtico que no concibe el ejercicio del pensamiento sino como una radical y obstinada puesta a prueba de toda verdad preestablecida. De allí la elección de la figura emblemática de Nietzsche: "Así, lo pensado por Nietzsche lo convierte aún hoy en un filósofo incómodo, agresivo, seductor, que da que pensar, y en quien parece cumplirse su propósito declarado tempranamente de ser alguien que se propone "actuar contra el tiempo presente y, de ese modo, sobre ese tiempo, y a favor, esperamos, de un tiempo por venir (De la utilidad y desventajas de la historia para la vida)". Todavía hoy Nietzsche continuará siendo un pensador intempestivo". Paradojalmente, José Jara interroga la democracia actual, porque está embargado por la crítica nietzscheana de la igualdad y su elogio del aristocratismo, y a la luz de una geografía distinta a la de las fronteras nacionales, él cuestiona a Europa y el mundo, del mismo modo que convoca a su manera el filosofema: "No hay fenómeno moral, solo hay interpretación moral de los fenómenos", para pensar el presente. 
Le conocí hace treinta años, ha sido desde el comienzo, un actor de la escena filosófica inédita que se instaló bajo la dictadura militar, al amparo de la Vicaría de la Solidaridad, de la Academia de Humanismo Cristiano, del Colegio Internacional de Filosofía y la Universidad de Paris 8. En 1990, él desvía el camino de los siete franceses que se dirigen en misión filosófica de París a Santiago, y organiza un coloquio memorable sobre la filosofía de la igualdad en la Universidad Simón Bolívar y en el Museo de Bellas Artes de Caracas. Desde entonces y hasta ahora, ya sea que él mismo organice encuentros en la Universidad de Valparaíso (citaré tan solo el memorable coloquio internacional sobre El filósofo griego y la sociedad de su tiempo), o bien que venga a dar conferencias en París en el Collège international de philosophie o en la Universidad de París 8, como profesor invitado, o aun, como últimamente en Sao Paulo, en el coloquio internacional Michel Foucault.

He tenido la suerte inaudita en mi vida filosófica de haber encontrado y tener por amigos a los más grandes filósofos chilenos contemporáneos, en un combate común. Ellos fueron excluidos o marginados de la universidad de su país por la dictadura militar. Para algunos, como Humberto Giannini, fue un exilio interior, para otros, como José Jara, un exilio en Venezuela - o podría ser en otra parte. Francia, Puerto Rico o Canadá, no cito a los que aún están vivos, ellos se reconocerán-. Más que cualquier otro, José Jara era un pensador del exilio. Para hablar como Adorno y Miguel Abensour: contra la mentira de la totalidad, los actos de disidencia abren un horizonte de esperanza que no podría existir sin desterrar la avidez y el sometimiento. Constatar que el tiempo de la casa ha pasado, negarse a habitar en el hogar suyo, llevar al límite el exilio, es preservar la posibilidad de vivir de otra manera, en una sociedad que realizaría idealmente al individuo en una verdadera dimensión social. El pensamiento del exilio procede, pues, de una inspiración utópica. "El pensar libre y que resiste apunta más allá de sí mismo", sin reificarse en una nueva utopía, en la ilusión de una vuelta al hogar. El retorno a Valparaíso habrá sido para Pepe Jara a imagen del de Ulises a Itaca. El paso por Nietzsche habrá sellado en él la exigencia del pensar, la modestia del pensador y el amor a la vida: "solo después de la muerte llegaremos a nuestra vida y estaremos vivos, ¡ah ! ¡muy vivos! Nosotros los hombres póstumos (Humano, demasiado humano, 365)”.

Patrice Vermeren Profesor de Filosofía, Universidad de París 8 Profesor honorario de la Universidad de Chile 